\title{
OBITUARIES
}

\section{Dr. J. B. Goodey}

Plant and soil nematodes have attracted few zoologists and it is all the more remarkable that the Goodeys, father and son, who trained, the first partly and the socond wholly, as botanists, should have become world authorities on one aspect of the subject, namely, identification and classification. Basil Goodey joined his father at Winches F\&urm, St. Albans, the field station of the London School of Hygiene and Tropical Medicine, about a year before the Department of Nematology moved to Rothamsted Experimental Station. Until his father's death in 1953 ho was mainly concerned with plant parasitic nematodes of the genus Ditylenchus, but afterwards he gradually assumed his father's role, published more than sixty scientific papers describing many new species and became increasingly interested in nematode taxonomy. He also undertook the revision of his father's books. Laboratory Methods for Work with Plant and Soil Nematodes was revised and enlarged three times. A supplement to The Nematode Parasites of Plants Catalogued under their Hosts was produced and then, with the holp of Dr. Mary Franklin and Mr. D. J. Hooper, the whole was completely revised shortly before he died. His greatest contribution to nematology, however, was the complete revision in 1963 of Soil and Freshwater Nematodes with descriptions and re-descriptions of many new genera and a new classification of major groups.

John Basil Goodey was born at Dorridge, Warwickshire, on May 10, 1914. Like his father ho was a Quaker. During the early years of the Second World War he was engaged in Quaker relief work and for several years served as Clerk to the Society of Friends in Harpenden. He was educated at City of London School and University College, London, where he took his degree in 1937 and was Quain student in botany for the next two years. From 1943 until 1947 he worked in the Oil Seeds and Weed Control Unit first in the Imperial College of Science and Technology and later in the Department of Agriculture, Ox.ford. In 1961 he was awarded a D.Sc. degree of the University of London for work on plant nematodes and, in 1964, was elected a Fellow of the Institute of Biology. In 1962 he lectured at Cornell University, and in 1964 assisted in a nematology course, the first of its kind in India, at the Indian Agricultural Research Institute, New Delhi, under the auspices of the Rockefeller Foundation. From 1959 he served on the editorial board of the international journal, Nematologica, doing much to raise the standards of taxonomic papers by publishing in that journal "Data to be Considered, Observed and, Where Possible, Reported upon when Presenting Descriptions of New Species". His illustrations of species were models of clarity and essentially diagrams without unnecessary artistic embellishment. Over the past 2 years he had become interested in numerical taxonomy and had prepared for the computer lists of characters of major groups. $\mathrm{H}_{e}$ was happiest advising, teaching or serving others and, because of him, many students as well as experienced nernatologists came to Rothamsted to learn to identify plant nematodes, or to work on the collection there, and samples for diagnosis were received from all over the world. Visitors from abroad were also welcomed in his home where, with Mrs. Goodey, they would spend the evening in discussions ranging from politics to literature and art.

While on his way to spend 18 months in New Zealand and Australia at the invitation of the New Zealand Department of Scientific and Industrial Research, he died of a heart attack on October 30,1965 , and was buried at sea. He leaves a widow, a daughter and two granddaughters.

F. G. W. JONES

\section{Prof. Frank Allen}

Frank Allen, late emeritus professor of physics at the University of Manitoba, died on November 19 at Winnipeg, Canada, aged ninety-one. Born in New Brunswick of United Empire Loyalist stock, he was a fellow schoolpupil of the late Lord Beaverbrook. Like Beaverbrook and many of his generation, he held fierce religious and political beliefs; these were only tempered by time and by his love for science.

$\mathrm{He}$ graduated from the University of New Brunswick in 1895 with highest honours in physics and chemistry and a Gold Medal in Latin. He was appointed high school principal the same year at the astonishingly early age of twenty-one. In five years he had saved enough money to take him to Cornell, where he took his Ph.D. in 1902 for work on physiological optics, a subject which absorbed him for the rest of his life. It might well have been otherwise, for at Cornell he became interested in Oliver Lodge's newly discovered thermionic diode. He allowed himself to be dissuaded by Nichols, his professor, from investigating the effect of adding a third, or grid, electrode. A few years later Lee de Forest did add a third electrode and promptly patented the amplifying triode valve. The era of electronics was born and de Forest made a fortune. Thereafter, Allen frequently and ruefully warned his research students to be wary of taking the advice of any professor.

In 1904 he accepted the founding chair of physics in the new University of Manitoba and remained there all his life, attaining Fellowship of the Royal Society of Canada in 1912 and honorary doctorates of both Manitoba and New Brunswick.

With an annual research budget which would be spent by a modern physics department in an afternoon, he and his small group of enthusiastic students were forced to use themselves as research equipment. He wrote some sixty substantial papers, articles and books, mostly on the sensory reflex. He confirmed the Helmholtz trichromatic theory of colour vision, and accurately quantified the Fechner law of the intensity of visual stimulus. Then he turned to the other senses and showed, one after another, that thoy too followed the same logarithmic law. His methods were elegant and simple: the critical frequency of repeated stimulus, the least observable incremont to a given stimulus and the effect of fatigue. All the senses, auditory, tactile, pain, pressure, heat, taste and muscular response, yielded to his persistence and ingenuity. Only the sense of smell defeated him; the olfactory reflex was too delicate and sensitive for the experimental techniques available to him. He never spared himself as subject; the senses of pain and taste, in particular, demanding considerable fortitude. He made much of his apparatus with his own hands, and brought a fine sense of craftsmanship to everything he did, whother it was making an instrument, carving a turkey or chopping wood, all three of which he much enjoyed.

$\mathrm{He}$ constantly preached the importance of science and the excitement of discovery, while for relaxation he delighted to write and converse in Latin, Greek and Hebrew. He outlived practically all his contemporaries and, indeed, many of his research students.

$\mathrm{H}_{\Theta}$ is survived by his two sons and daughter.

$$
\text { J. F. AlLen }
$$

